Suska Journal of Mathematics Education

Vol.2, No. 1, 2016, Hal. 20 - 30

\title{
Pengaruh Pendekatan Pembelajaran Visual Thinking Disertai Aktivitas Quick On The Draw Terhadap Kemampuan Komunikasi Matematis Siswa
}

\author{
Rezi Ariawan \\ Program Studi Pendidikan Matematika, Fakultas Keguruan dan Ilmu \\ Pendidikan, Universitas Islam Riau \\ Email: ariawanrezi@ rocketmail.com
}

*Submitted :19-02-2016 *Accepted : 19-03-2016

\begin{abstract}
ABSTRAK. Penelitian ini didasarkan pada permasalahan rendahnya kemampuan komunikasi matematis siswa. Untuk mengatasi hal tersebut, dilakukan penelitian dengan menggunakan pendekatan pembelajaran Visual Thinking disertai aktivitas Quick on the Draw. Penelitian ini mengkaji masalah peningkatan kemampuan komunikasi matematis antara siswa yang mendapat pendekatan pembelajaran Visual Thinking disertai aktivitas Quick on the Draw dan pendekatan pembelajaran konvensional ditinjau dari keseluruhan siswa dan kemampuan awal matematis siswa (tinggi, sedang, dan rendah). Penelitian ini merupakan penelitian kuasi eksperimen dengan desain penelitian Nonequivalent Control Group Design menggunakan teknik Purposive Sampling. Populasi dalam penelitian ini adalah siswa kelas VIII SMP di Kota Pekanbaru Riau Tahun Pelajaran 2012/2013. Sedangkan sampel dalam penelitian ini adalah siswa kelas VIII di salah satu SMP di Kota Pekanbaru Riau. Instrumen yang digunakan dalam penelitian ini adalah tes kemampuan komunikasi matematis. Analisis kuantitatif dilakukan dengan menggunakan uji perbedaan rataan. Hasil penelitian menunjukkan bahwa peningkatan kemampuan komunikasi matematis siswa yang mendapat pendekatan pembelajaran Visual Thinking disertai aktivitas Quick on the Draw lebih baik daripada siswa yang
\end{abstract}


mendapat pembelajaran konvensional ditinjau dari keseluruhan siswa dan kemampuan awal matematis (tinggi, sedang, dan rendah)

Kata kunci : pendekatan pembelajaran visual thinking, aktivitas quick on the draw, kemampuan komunikasi matematis

\section{PENDAHULUAN}

Pentingnya pembelajaran matematika sebagai bagian dari proses pendidikan telah dinyatakan di dalam Kurikulum Tingkat Satuan Pendidikan (KTSP). Depdiknas (2006: 345) menyatakan bahwa mata pelajaran matematika perlu diberikan kepada semua peserta didik mulai dari Sekolah Dasar untuk membekali peserta didik dengan kemampuan berpikir logis, analitis, sistematis, kritis, dan kreatif, serta kemampuan bekerjasama. Kompetensi tersebut diperlukan agar peserta didik dapat memiliki kemampuan memperoleh, mengelola, dan memanfaatkan informasi untuk bertahan hidup pada keadaan yang selalu berubah, tidak pasti dan kompetitif.

Hal ini sejalan dengan apa yang dikemukan oleh Sabandar (2008), dimana pembelajaran matematika di sekolah tidak hanya bertujuan agar siswa memahami materi matematika yang diajarkan, tetapi tujuan-tujuan utama lainnya, yaitu agar siswa memiliki kemampuan penalaran matematika, komunikasi matematika, koneksi matematika, representasi matematika dan pemecahan masalah matematika, serta perilaku tertentu yang harus siswa peroleh setelah ia mempelajari matematika.

Diantara kemampuan-kemampuan yang dikemukakan oleh Sabandar di atas, kemampuan komunikasi matematis merupakan dua kemampuan yang sangat diperlukan oleh setiap orang dalam menghadapi kehidupan, terutama dalam era globalisasi dan informasi seperti saat ini. Kemampuan komunikasi matematis merupakan kemampuan yang telah dinyatakan secara tertulis di dalam tujuan mata pembelajaran matematika pada pendidikan dasar dan menengah yang tercantum di dalam Kurikulum Tingkat Satuan Pendidikan (KTSP) 2006. KTSP mengemukakan agar peserta didik memiliki kemampuan: (1) Memahami konsep matematika, menjelaskan keterkaitan antarkonsep dan mengaplikasikan konsep atau logaritma, secara luwes, akurat, efisien, dan tepat dalam pemecahan masalah; (2) Menggunakan penalaran pada pola dan sifat, melakukan manipulasi matematika dalam membuat generalisasi, menyusun bukti, atau menjelaskan gagasan dan pernyataan matematika; (3) Memecahkan masalah yang meliputi kemampuan memahami masalah, merancang model matematika, menyelesaikan model dan menafsirkan solusi yang diperoleh; (4) Mengkomunikasikan gagasan dengan simbol, tabel, diagram, atau media untuk memperjelas keadaan atau masalah; (5) Memiliki sikap menghargai kegunaan matematika dalam kehidupan, yaitu memiliki rasa ingin tahu, perhatian, dan minat dalam mempelajari matematika, serta sikap ulet dan percaya diri dalam pemecahan masalah. 
Berdasarkan paparan di atas, maka kemampuan komunikasi matematis merupakan kemampuan yang sangat penting dan menjadi fokus utama untuk dikembangkan dan dimiliki oleh siswa melalui pembelajaran matematika di sekolah.

Ui Hock (2009) menyatakan bahwa pengembangan kemampuan komunikasi matematis sejatinya tidak terlepas dari kompetensi matematika lainnya, yaitu penalaran, koneksi, dan pemecahan masalah. Pentingnya pengembangan kemampuan komunikasi matematis siswa dikarenakan melalui komunikasi matematis, siswa dapat mengorganisasikan ide dan berpikir matematisnya baik secara lisan maupun tulisan.

Kusumah (2008) menyatakan bahwa komunikasi merupakan bagian yang sangat penting dalam pembelajaran matematika, karena melalui komunikasi (1) ide matematis dapat dieksploitasi dalam berbagai perspektif; (2) cara berfikir siswa dapat dipertajam; (3) pertumbuhan pemahaman dapat diukur; (4) pemikiran siswa dapat dikonsolidasi dan diorganisir; (5) pengetahuan matematis dan pengembangan masalah siswa dikontruksi; (6) penalaran siswa dapat ditingkatkan; dan (7) komunikasi siswa dapat dibentuk.

Clark (Hutapea, 2013) menyatakan bahwa untuk dapat meningkatkan kemampuan komunikasi matematis siswa dapat diberikan 4 strategi, yaitu (1) memberikan tugas-tugas yang cukup memadai, sehingga membuat siswa maupun kelompok diskusi menjadi lebih aktif; (2) menciptakan lingkungan yang kondusif bagi siswa dalam mengungkapkan ide atau gagasannya; (3) mengarahkan siswa untuk menjelaskan dan memberikan argumentasi pada hasil yang diberikan dan ide atau gagasan yang dipikirkan; (4) mengarahkan siswa untuk aktif memperoleh berbagai macam ide atau gagasannya.

Mengingat pentingnya kemampuan komunikasi matematis dalam pembelajaran matematika, maka kemampuan komunikasi matematis harus ditingkatkan. Kenyataan dilapangan menunjukkan bahwa kemampuan komunikasi matematis siswa masih rendah. Rohaeti (2003) menyatakan bahwa rata-rata KKM siswa berada pada kualifikasi kurang dalam mengkomunikasikan ide-ide matematika termasuk dalam kategori kurang sekali. Selanjutnya Firdaus (2005) menyatakan bahwa kemampuan komunikasi matematis siswa yang memperoleh pembelajaran dalam kelompok kecil tipe Team-Assited-Individualization (TAI) berbasis masalah masih tergolong rendah. Hal ini terlihat dari perolehan skor kemampuan komunikasi matematis siswa $\pm 60 \%$ dari skor ideal.

Beberapa uraian di atas mengindikasikan bahwa kemampuan kemampuan komunikasi matematis perlu untuk ditingkatkan, karena kemampuan tersebut merupakan kemampuan yang harus dimiliki oleh siswa untuk kebutuhan kini dan kebutuhan masa akan datang

Kondisi saat ini di lapangan, pada umumnya menunjukkan bahwa aktivitas pembelajaran masih didominasi oleh guru, siswa masih belum berperan aktif dalam pembelajarannya. Ruseffendi (1991) menyatakan bahwa matematika yang diberikan di sekolah sebagian besar diperoleh melalui pemberitahuan oleh guru, sehingga 
membuat siswa menjadi pasif. Siswa hanya mengulangi algoritma dan prosedur yang telah dijelaskan oleh guru dalam mengerjakan soal rutin (driil). Model pembelajaran seperti ini menurut Brooks and Brooks (Hutapea, 2013) disebut pembelajaran konvensional. Oleh sebab itu, perlu rasanya diadakan penerapan pembelajaran modern di dalam pembelajaran matematika, karena pembelajaran konvensional kurang dapat mengembangkan kemampuan berpikir tingkat tinggi.

Salah satu variasi pembelajaran yang dapat dilakukan oleh guru untuk mengatasi kesulitan dalam proses komunikasi matematis siswa adalah pendekatan pembelajaran Visual Thinking. Berpikir visual (Visual Thinking) dapat menjadi salah satu alternatif untuk mempermudah siswa dalam mempelajari matematika. Hal ini sejalan dengan apa yang dikemukan oleh Surya (2011: 194) yang menyatakan bahwa siswa biasanya mengalami kesulitan menjembatani pengetahuan informal ke matematika sekolah. Siswa perlu bimbingan dan bantuan khusus pada bentuk representasi pemikiran visual (Visual Thinking) dari apa yang mereka maksud atau mereka pikirkan sehingga dapat divisualisasikan dalam bentuk struktur ide, ide tersebut bisa sebagai angka, simbol, gambar, diagram, penjelasan model, lukisan yang dapat membantu siswa dalam proses belajar dan menyelesaikan permasalahan matematika mereka.

Presmeg (Surya, 2011) mengungkapkan tujuh peranan visual thinking, yaitu: (1) Untuk memahami masalah, dengan merepresentasikan masalah visual siswa dapat memahami bagaimana unsur-unsur dalam masalah berhubungan satu sama lain; (2) Untuk menyederhanakan masalah, visualisasi memungkinkan siswa mengidentifikasi masalah versi yang lebih sederhana, pemecahan masalah dan kemudian memformalkan pemahaman soal yang diberikan dan mengidentifikasi metode yang digunakan untuk masalah yang serupa; (3) Untuk melihat keterkaitan (koneksi) masalah; (4) Untuk memahami gaya belajar individual, setiap siswa memiliki gaya tersendiri ketika menggunakan representasi visual saat pemecahan masalah; (5) Sebagai pengganti komputasi/penghitungan, penyelesaian masalah dapat diperoleh secara langsung melalui representasi visual itu sendiri, tanpa penghitungan; (6) Sebagai alat untuk memeriksa solusi, representasi visual dapat digunakan untuk memeriksa kebenaran jawaban yang diperoleh; (7) Untuk mengubah masalah ke dalam bentuk matematis, bentuk matematis dapat diperoleh dari representasi visual dalam pemecahan masalah.

Langkah-langkah Visual Thinking menurut Bolton (Nurdin, 2012: 29) adalah: (1) Looking, pada tahap ini, siswa megidentifikasi masalah dan hubungan timbal baliknya, merupakan aktivitas melihat dan mengumpulkan; (2) Seeing, mengerti masalah dan kesempatan, dengan aktivitas menyeleksi dan mengelompokkan; (3) Imagining, mengeneralisasikan langkah untuk menemukan solusi, kegiatan pengenalan pola; (4) Showing and Telling, menjelaskan apa yang dilihat dan diperoleh kemudian mengkomunikasikannya

Untuk melakukan pemecahan masalah maka siswa lebih baik dibelajarkan dalam kelompok. Menurut Hutagaol (2012: 5) siswa yang belajar dalam kelompok 
kecil lebih menerapkan kegiatan pemecahan masalah dibandingkan dengan siswa yang bekerja secara individu. Sejalan dengan itu, Thorndike (Hutagaol, 2012: 5) menyimpulkan bahwa faedah pemecahan masalah dilakukan secara berkelompok, yaitu: (1) kelompok lebih banyak membawa pengalaman masing-masing daripada pengalaman individu; (2) kelompok lebih banyak memberikan bermacam-macam saran/pendapat dibandingkan dengan seorang individu saja; (3) macam-macam pendapat yang berbeda lebih representatif daripada pendapat seorang saja; (4) dalam menyatukan perbedaan-perbedaan pendapat akan menjadi masalah yang lebih riil; (5) kelompok lebih produktif dalam memberikan kritik terhadap usul-usul.

Berdasarkan pendapat di atas, maka dalam penelitian ini diajukan aktivitas Quick on the Draw. Aktivitas Quick on the draw kental dengan kegiatan perlombaan, dimana siswa akan memperoleh kesempatan bekerjasama. Ginnis (2008: 163-164) menyatakan bahwa aktivitas Quick on the Draw merupakan sebuah aktivitas riset untuk kerja tim dan kecepatan yang dapat mendorong kerja kelompok. Aktivitas ini berupa pacuan antar kelompok yang bertujuan mencari kelompok pertama yang dapat menyelesaikan satu set pertanyaan. Semakin efisien kerja kelompok, maka semakin cepat kemajuan kelompoknya.

Ginnis (2008: 163) menyatakan bahwa aktivitas quick on the draw dapat dilakukan dengan 9 langkah, diantaranya yaitu: (1) Siapkan satu set pertanyaan, misalnya sepuluh, mengenai topik yang sedang dibahas. Buat cukup salinan agar tiap kelompok punya sendiri (tiap kelompok memiliki satu set pertanyaan sendiri dan setiap pertanyaan harus dikartu terpisah). Tiap set pertanyaan sebaiknya di kartu dengan warna yang berbeda. Letakkan set pertanyaan tersebut di atas meja guru, angka menghadap ke atas dan angka nomor diletakkan paling atas; (2) Bagi kelas ke dalam kelompok-kelompok kecil. Beri warna untuk tiap kelompok sehingga mereka dapat mengenali set pertanyaan mereka di meja guru; (3) Tiap siswa dalam tiap kelompok diberi materi yang terdiri dari jawaban untuk semua jawaban, bisa berupa halaman tertentu dari buku teks yang biasanya. Jawaban sebaiknya tidak begitu jelas agar siswa berinisiatif untuk mencari jawaban lengkapnya di buku teks; (4) Pada kata "mulai", satu orang (orang pertama) dari tiap kelompok berjalan ke meja guru, mengambil pertanyaan pertama menurut warna mereka dan kembali membawanya ke kelompok; (5) Kelompok tersebut berdiskusi mencari jawaban pertanyaan dan kemudian jawaban ditulis di lembar kertas terpisah; (6) Setelah selesai, jawaban diberikan kepada guru oleh orang kedua. Guru memeriksa jawaban. Jika jawaban akurat dan lengkap, pertanyaan kedua dari tumpukan warna mereka dapat diambil. Begitu seterusnya. Jika ada jawaban yang tidak akurat atau tidak lengkap, guru menyuruh siswa tersebut kembali ke kelompok dan mencoba lagi. Siswa yang menulis, mengambil pertanyaan, dan mengembalikan jawaban harus bergantian; (7) Saat satu siswa sedang mengembalikan jawaban, siswa yang lain menandai sumbernya dan membiasakan diri dengan isinya, sehingga mereka dapat menjawab pertanyaan selanjutnya dengan lebih efisien; (8) Kelompok yang menang adalah 
yang pertama menjawab semua pertanyaan; (9) Guru bersama siswa menjawab semua pertanyaan dan siswa membuat catatan tertulis.

Berdasarkan latar belakang dan pentingnya masalah yang dikemukakan, maka masalah yang dikaji dalam penelitian ini adalah: (1) Apakah peningkatan kemampuan komunikasi matematis siswa yang mendapatkan pendekatan pembelajaran Visual Thinking disertai aktivitas Quick on The Draw lebih baik daripada siswa yang mendapat pembelajaran konvensional?; (2) Apakah peningkatan kemampuan komunikasi matematis siswa yang mendapatkan pendekatan pembelajaran Visual Thinking disertai aktivitas Quick on The Draw lebih baik daripada siswa yang mendapatkan pembelajaran konvensional bila ditinjau dari kemampuan awal matematis siswa (tinggi, sedang, dan rendah)?

\section{METODE PENELITIAN}

Penelitian ini merupakan penelitian kuasi eksperimen dengan desain penelitian yang digunakan Non-equivalent Control Group Design (Ruseffendi, 2005: 52). Populasi dalam penelitian ini adalah siswa SMP kelas delapan di Kota Pekanbaru Tahun Pelajaran 2012/2013. Pengambilan sampel dalam penelitian ini dilakukan dengan menggunakan teknik purposive sampling. Sampel yang digunakan dalam penelitian ini adalah kelas VIII-3 dan VIII- 4 di salah satu SMP di Kota Pekanbaru. Instrumen yang digunakan dalam penelitian ini adalah instrumen tes kemampuan pemecahan masalah dan komunikasi matematis siswa.

\section{HASIL PENELITIAN DAN PEMBAHASAN}

\section{Peningkatan Kemampuan Komunikasi Matematis Berdasarkan Pembelajaran}

Berikut gambaran umum rataan $\mathrm{N}$-gain kemampuan komunikasi matematis berdasarkan pembelajaran.

Tabel 1. Rataan N-gain Kemampuan Komunikasi Matematis

\begin{tabular}{|c|c|c|}
\hline Kelas & Rataan N-gain & Klasifikasi \\
\hline Eksperimen & 0,83 & Tinggi \\
\hline Kontrol & 0,29 & Rendah \\
\hline
\end{tabular}

Tabel 1 di atas memperlihatkan bahwa rataan $\mathrm{N}$-gain kelas eksperimen sebesar 0,83 dengan klasifikasi tinggi, sementara rataan n-gain kelas kontrol sebesar 0,24 dengan klasifikasi rendah. Dengan demikian dapat kita simpulkan bahwa rataan $\mathrm{N}$-gain kemampuan komunikasi matematis kelas eksperimen lebih besar dibandingkan rataan $\mathrm{N}$-gain kemampuan komunikasi matematis kelas kontrol. Untuk menunjukkan bahwa rataan skor $\mathrm{N}$-gain kemampuan komunikasi matematis matematis siswa kelas eksperimen lebih baik daripada kelas kontrol dilakukan uji perbedaan rataan skor N-gain dengan menggunakan uji nonparametric (MannWhitney). Berikut rangkuman hasil uji perbedaan rataan skor $\mathrm{N}$-gain pada taraf signifikan $\alpha=0,05$, 
$H_{0}$ : Peningkatan kemampuan komunikasi matematis siswa yang mendapat pembelajaran dengan pendekatan Visual Thinking disertai aktivitas Quick on the Draw sama dengan siswa yang menggunakan pembelajaran konvensional.

Tabel 2. Data Hasil Uji Perbedaan Rataan Skor N-gain Kemampuan Komunikasi Matematis

\begin{tabular}{|l|c|c|c|}
\hline \multicolumn{1}{|c|}{ Statistik } & Nilai & Keterangan & Kesimpulan \\
\hline Mann-Whitney U & 110,000 & & \\
\cline { 1 - 2 } & $-6,793$ & \multirow{2}{*}{$\mathrm{H}_{0}$ Ditolak } & \multirow{2}{*}{ Hipotesis diterima } \\
\cline { 1 - 2 } Asymp. Sig. (2-tailed) & 0,000 & & \\
\hline Asymp. Sig. (1-tailed) & 0,000 & & \\
\hline
\end{tabular}

Dari hasil uji Mann-Whitney di atas didapat nilai p-value atau Sig. (1-tailed) yaitu $0,000<\alpha=0,05$. Hal ini menunjukkan bahwa $\mathrm{H}_{\mathrm{o}}$ ditolak, artinya peningkatan kemampuan komunikasi matematis siswa yang mendapat pembelajaran dengan menggunakan pendekatan pembelajaran Visual Thinking disertai aktivitas Quick on the Draw lebih baik daripada siswa yang mendapat pembelajaran konvensional secara keseluruhan.

\section{Peningkatan Kemampuan Komunikasi Matematis Berdasarkan Kemampuan Awal Matematis dan Pembelajaran}

Berikut gambaran umum rataan peningkatan kemampuan komunikasi matematis berdasarkan kemampuan awal matematis dan pembelajaran.

Tabel 3. Rataan N-gain Kemampuan Komunikasi Matematis Berdasarkan Kemampuan Awal Matematis

\begin{tabular}{|c|c|c|c|c|}
\hline \multicolumn{2}{|c|}{ Kemampuan yang diukur } & \multicolumn{3}{|c|}{ Kemampuan Kom. Matematis } \\
\hline \multicolumn{2}{|c|}{ Model Pembelajaran } & PE & PK & Rataan \\
\hline \multirow{2}{*}{$\begin{array}{c}\text { Kategori } \\
\text { KAM }\end{array}$} & Tinggi & 0,82 & 0,32 & 0,50 \\
\cline { 2 - 5 } & Sedang & 0,79 & 0,31 & 0,48 \\
\cline { 2 - 5 } & Rendah & 0,94 & 0,25 & 0,69 \\
\hline
\end{tabular}

Berdasarkan tabel 3 di atas diperoleh informasi bahwa pada kategori KAM rendah siswa yang mendapat pendekatan pembelajaran Visual Thinking disertai aktivitas Quick on the Draw memperoleh peningkatan yang lebih tinggi jika dibandingkan dengan siswa pada kategori KAM tinggi dan sedang. Hal ini dapat dilihat dari perbedaan rataan $\mathrm{N}$-gain kemampuan komunikasi matematis siswa pada setiap kategori KAM, untuk kategori KAM atas perbedaannya sebesar 0,5, kategori KAM sedang perbedaannya sebesar 0,48 dan untuk kaategori rendah perbedaan rataan $\mathrm{N}$-gainnya sebesar 0,69 .

Pada kelompok siswa yang mendapat pendekatan pembelajaran Visual Thinking disertai aktivitas Quick on the Draw dan pendekatan konvensional terdapat perbedaan rataan peningkatan kemampuan komunikasi matematis. Kelompok siswa yang mendapat pembelajaran Visual Thinking disertai aktivitas Quick on the Draw 
anatara KAM tinggi dan dengan sedang terdapat perbedaan sebesar 0,03 , antara KAM kategori tinggi dengan rendah terdapat perbedaan sebesar 0,12 , dan antara KAM kategori sedang dengan rendah terdapat perbedaan sebesar 0,15 .

Sedangkan kelompok siswa yang mendapat pendekatan pembelajaran konvensional, antara kategori KAM tinggi dengan sedang terdapat perbedaan sebesar 0,01, antara KAM kategori tinggi dengan rendah terdapat perbedaan sebesar 0,07, dan antara KAM kategori sedang dengan rendah terdapat perbedaan sebesar 0,06. Fakta ini menunjukkan bahwa semakin tinggi KAM yang dimiliki siswa maka semakin tinggi kemampuan komunikasi matematis yang diperolehnya. Hal ini mengindikasikan bahwa terdapat hubungan antara KAM yang dimiliki siswa dengan kemampuan komunikasi matematis.

Untuk mengetahui apakah terdapat perbedaan peningkatan kemampuan komunikasi matematis siswa yang mendapat pendekatan pembelajaran Visual Thinking disertai aktivitas Quick on the Draw (kelas eksperimen) dan siswa yang mendapat pembelajaran dengan pendekatan konvensional (kelas kontrol) ditinjau dari kemampuan awal matematika (tinggi, sedang, dan rendah), perlu dilakukan pengujian perbedaan rataan skor $\mathrm{N}$-gain.

Berikut rangkuman hasil uji perbedaan rataan skor $\mathrm{N}$-gain pada taraf signifikansi $\alpha=0,05$.

$H_{0}$ : $\quad$ Peningkatan kemampuan komunikasi matematis siswa yang mendapatkan pendekatan pembelajaran Visual Thinking disertai aktivitas Quick on the Draw sama dengan siswa yang mendapatkan pembelajaran konvensional, bila ditinjau dari kemampuan awal matematis siswa (tinggi, sedang, dan rendah)

Tabel 4. Data Hasil Uji Perbedaan Rataan Skor N-gain

Kemampuan Komunikasi Matematis

Berdasarkan Kemampuan Awal Matematis dan Pembelajaran

\begin{tabular}{|c|c|c|c|c|}
\hline KAM & Pembelajaran & $\begin{array}{c}\text { Perbandingan } \\
\text { Rataan }\end{array}$ & Sig. & Kesimpulan \\
\hline Tinggi & PVT $:$ PK & $0,82: 0,32$ & 0,007 & $\mathrm{H}_{0}$ Ditolak \\
\hline Sedang & PVT $:$ PK & $0,79: 0,31$ & 0,001 & $\mathrm{H}_{0}$ Ditolak \\
\hline Rendah & PVT $:$ PK & $0,94: 0,25$ & 0,000 & $\mathrm{H}_{0}$ Ditolak \\
\hline
\end{tabular}

Berdasarkan tabel 4 di atas dapat disimpulkan bahwa untuk kategori kemampuan awal matematika siswa kategori tinggi, sedang, dan rendah, peningkatan kemampuan komunikasi matematis siswa yang mendapat pendekatan pembelajaran Visual Thinking disertai aktivitas Quick on the Draw lebih baik daripada siswa yang mendapat pembelajaran konvensional.

\section{PENUTUP}

\section{Kesimpulan}

Berdasarkan hasil pengolahan data, analisis, temuan dan pembahasan diperoleh kesimpulan sebagai berikut: 
1. Peningkatan kemampuan komunikasi matematis siswa yang pembelajarannya dengan menggunakan pendekatan pembelajaran Visual Thinking disertai aktivitas Quick on the Draw secara signifikan lebih baik dibandingkan dengan siswa yang pembelajarannya dengan menggunakan pendekatan pembelajaran konvensional.

2. Peningkatan kemampuan komunikasi matematis siswa yang mendapat pendekatan pembelajaran Visual Thinking disertai aktivitas Quick on the Draw secara signifikan lebih baik dibandingkan dengan siswa yang pembelajarannya dengan menggunakan pendekatan pembelajaran konvensional, bila ditinjau dari kategori kemampuan awal matematis siswa tinggi.

3. Peningkatan kemampuan komunikasi matematis siswa yang mendapat pendekatan pembelajaran Visual Thinking disertai aktivitas Quick on the Draw secara signifikan lebih baik dibandingkan dengan siswa yang pembelajarannya dengan menggunakan pendekatan pembelajaran konvensional, bila ditinjau dari kategori kemampuan awal matematis siswa sedang.

4. Peningkatan kemampuan komunikasi matematis siswa yang mendapat pendekatan pembelajaran Visual Thinking disertai aktivitas Quick on the Draw secara signifikan lebih baik dibandingkan dengan siswa yang pembelajarannya dengan menggunakan pendekatan pembelajaran konvensional, bila ditinjau dari kategori kemampuan awal matematis siswa rendah.

\section{Rekomendasi}

1. Pendekatan pembelajaran Visual Thinking disertai aktivitas Quick on the Draw hendaknya menjadi alternatif pendekatan pembelajaran bagi guru SMP khususnya untuk meningkatkan kemampuan pemecahan masalah dan komunikasi matematis siswa

2. Perlu diadakan sosialisasi kepada guru tentang pentingnya kemampuan komunikasi matematis serta pengembangannya dalam pembelajaran

3. Jika guru ingin mengimplementasikan pendekatan pembelajaran Visual Thinking disertai aktivitas Quick on the Draw, maka sebaiknya guru memperhitungkan setiap kegiatan yang akan dilakukan agar waktu yang tersedia mencukupi untuk melaksanakan pendekatan pembelajaran tersebut

4. Penerapan pendekatan pembelajaran Visual Thinking disertai aktivitas Quick on the Draw di kelas, hendaknya disertai dengan lebih banyak latihan-latihan soal yang bervariasi yang dapat meningkatkan kemampuan matematika siswa

5. Bagi peneliti selanjutnya, penelitian ini dapat direnovasi dengan menyertakan aktivitas pembelajaran lainnya dalam penerapan pendekatan pembelajaran Visual Thinking; (6)Bagi peneliti selanjutnya, jika ingin menerapkan pendekatan pembelajaran Visual Thinking disertai aktivitas Quick on the Draw, sebaiknya memilih materi yang cocok, karena tidak semua materi cocok untuk disampaikan dengan pendekatan pembelajaran ini. 


\section{DAFTAR PUSTAKA}

Departemen Pendidikan Nasional. (2006). Panduan Penyusunan Kurikulum Tingkat Satuan Pendidikan Jenjang Pendidikan Dasar dan Menengah. Jakarta: BSNP.

Firdaus. (2005). Meningkatkan Kemampuan Komunikasi Matematika Siswa Melalui Pembelajaran dalam Kelompok Kecil Tipe Team Assisted Individualization (TAI) dengan Pendekatan Berbasis Masalah. Tesis Universitas Pendidikan Indonesia. Tidak Diterbitkan.

Ginnis, P. (2008). Trik dan Taktik Mengajar. Jakarta: PT. Indeks.

Hutagaol, K. (2012). Strategi Multi Representasi dalam Kelompok Kecil untuk Meningkatkan Kemampuan Pemecahan Masalah dan Komunikasi Matematis Siswa SMP. Disertasi Universitas Pendidikan Indonesia. Tidak Diterbitkan.

Hutapea, N. M. (2013). Peningkatan Kemampuan Penalaran, Komunikasi Matematis dan Kemandirian Belajar Siswa SMA Melalui Pembelajaran Generatif. Disertasi Universitas Pendidikan Indonesia. Tidak Diterbitkan.

Kusumah, Y. (2008). Konsep Pengembangan dan Implementasi Computer Based Learning dalam Meningkatkan Kemampuan High Order Mathematical Thinking. Pidato pada Pengukuhan Jabatan Guru Besar Tetap dalam Bidang Pendidikan Matematika pada FPMIPA UPI, Bandung.

Nurdin, E. (2012). Meningkatkan Kemampuan Pemecahan Masalah dan Koneksi Matematis Siswa Melalui Pendekatan Pembelajaran Visual Thinking. Tesis Universitas Pendidikan Indonesia. Tidak Diterbitkan.

Rohaeti, E. E. (2003). Pembelajaran dengan Metode IMPROVE untuk Meningkatkan Pemahaman dan Kemampuan Komunikasi Matematik Siswa SLTP. Tesis Universitas Pendidikan Indonesia. Tidak Diterbitkan.

Ruseffendi, H. E. T. (1991). Pengantar Kepada Membantu Guru Mengembangkan Kompetensinya dalam Pengajaran Matematika untuk Meningkatkan CBSA. Bandung: Transito.

. (2005). Dasar-dasar Penelitian Pendidikan dan Bidang Non Eksakta Lainnya. Bandung :Tarsito.

Sabandar, J. (2007). Berpikir Reflektif. Makalah disampaikan pada Seminar Nasional Sehari: Permasalahan Matematika dan Pendidikan Matematika Terkini tanggal 8 Desember 2007. UPI Bandung: Tidak Diterbitkan.

Surya, E. (2011). Visual Thinking and Mathematical Problem Solving of the Nation Character Development. International Seminar and the Fourth National Conference on Mathematics Education. 
Ui Hock, C. (2007). Conceptualizating a Framework for Mathematics Communication in Malaysian Primary Schools. Paper for The Third APECTsukuba International Conference. Innovation of Classroom Teacing and Learning Through Lesson Study-Focusing on Mathematical Communication. Tokyo and Kanazawa (Kyoto), Japan. 